\title{
PENGARUH STORY TELLING TERHADAP POLA KONSUMSI SAYUR DAN BUAH PADA ANAK USIA PRASEKOLAH DI TK AL- ISHLAH KABUPATEN CIREBON
}

\section{EFFECT OF STORY TELLING ON CONSUMPTION PATTERNS VEGETABLES AND FRUITS IN CHILDREN AGE PRASEKOLAH IN TK AL-ISHLAH DISTRICT CIREBON}

\author{
Supriatin ${ }^{1}$ Indri Nasihah Nusya ${ }^{2}$ \\ Supriatin: Program Studi Ilmu Keperawatan STIKes Cirebon, \\ Kampus Jl.Brigjen Dharsono No.12B Cirebon, Jawa Barat \\ E-mail: supriatin98@yahoo.co.id
}

\begin{abstract}
ABSTRAK
Pendahuluan : Usia prasekolah (3-6 tahun) merupakan masa perkembangan sosial, intelektual dan emosional yang pesat bagi anak. Anak membutuhkan asupan gizi yang adekuat untuk mencapai pertumbuhan dan perkembangan yang optimal.Salah satu intervensi keperawatan untuk membantu membantu meningkatkan konsumsi sayur dan buah pada anak usia prasekolah adalah dengan terapi story telling. Tujuan : Penelitian ini bertujuan untuk mengetahui pengaruh story telling terhadap tingkat konsumsi sayur dan buah pada anak usia prasekolah di Tk Al-Ishlah Kabupaten Cirebon. Metode : Jenis penelitian ini menggunakan desain penelitian quasi eksperimental design yaitu dengan pendekatan one group pretest posttest design menggunakan satu kelompok subjek. Pengambilan sampel menggunakan purposive sampling dengan jumlah sampel 32 responden. Tingkat konsumsi sayur dan buah diukur dengan menggunakan quesioner FFQ (Food Frequency Questioner). Analisis data yang digunakan adalah uji Wilcoxon. Hasil : Dari hasil uji statistik didapatkan nilai $p$ value adalah 0,000 dengan demikian $p$ value $<a 0,05$ yang berarti terdapat pengaruh story telling terhadap tingkat konsumsi sayur dan buah pada anak usia prasekolah di Tk Al-Ishlah Kabupaten Cirebon. Diskusi: Disarankan agar penelitian ini dapat digunakan sebagai referensi penelitian yang lebih luas, meneliti faktor yang lebih kompleks dengan populasi yang lebih besar.
\end{abstract}

Kata Kunci : pre anak usia prasekolah, story telling, tingkat konsumsi sayur dan buah.

\begin{abstract}
Introduction: Preschool (3-6 years) was a period of social development, intellectual and emotional rapid for children. Children need adequate nutrition to achieve growth and development optimal.Salah a nursing interventions to help help increase fruit and vegetable consumption in preschool children is by therapeutic storytelling. Purpose: This study aimed to determine the effect of the story telling of the level of fruit and vegetable consumption in preschool children in Nursery Al-Islah Cirebon in 2017. Method: This research uses quasi-experimental research design approach to design that one group pretest posttest design using one group of subjects. Sampling using purposive sampling with a sample of 32 respondents. The level of fruit and vegetable consumption was measured using questionnaires FFQ (Food Frequency Questionnaire). Analysis of the data used is the Wilcoxon test. Results: From the test results obtained statistical $p$ value is 0.000 thus $p$ value $<0.05$, which means there is a story telling effect on the level of fruit and vegetable consumption in preschool children in Nursery Al-Islah Cirebon in 2017. Discussion: It is recommended that this study be used as a broader research reference, examining more complex factors with larger populations.
\end{abstract}

Keywords: pre preschoolers, story telling, the level of consumption of vegetables and fruit

\section{SKOLASTIK} KEPERAWATAN

Vol, 4, No. 1 Januari - Juni 2018

ISSN: $2443-0935$ E-ISSN 2443 - 1699 


\section{PENDAHULUAN}

Gizi masih menjadi permasalahan dunia yang belum teratasi hingga saat ini. Hampir seluruh kelompok umur mengalami masalah pemenuhan gizi. Usia bayi dan balita menjadi fokus perhatian karena pada periode ini terjadi pertumbuhan dan perkembangan yang menentukan kualitas kehidupan selanjutnya. Pada usia ini, lebih dari separuh kematian disebabkan oleh masalah gizi. Data WHO menggambarkan $35 \%$ anak meninggal akibat kekurangan gizi. Salah satu faktor yang menyebabkan gizi kurang adalah sulit makan. Sulit makan adalah masalah yang sering dijumpai pada balita . Sulit makan adalah suatu kondisi yang ditandai dengan memainkan makanan, tidak tertarik pada makanan dan bahkan penolakan terhadap makanan. Jika balita ingin terpenuhi asupan gijinya maka konsumsi makanan sesuai dengan porsinya (Putri Widita Muharyani,2014)

Proporsi yang cukup besar pada anak di dunia yang tidak memenuhi rekomendasi WHO dalam konsumsi sayur dan buah, yakni setidaknya 400 gram/hari. Hal ini disebabkan karena anak sudah dapat memilih-milih makanan yang disukainya, hanya mau makan makanan tertentu saja dan cenderung menghindari makan sayur. Diperkirakan sebanyak $80 \%$ anak-anak di dunia ini yang tidak menyukai sayurmayur sedangkan sayur-mayur merupakan penyumbang utama untuk nutrisi dan diet seimbang pada anak-anak dan dewasa.

Sebuah penelitian oleh The Gates head Millenium Baby Study di Inggris menyebutkan $20 \%$ orang tua melaporkan anaknya mengalami masalah makan, dengan prevalensi tertinggi anak hanya mau makan makanan tertentu. Survei lain di Amerika Serikat menyebutkan 19-50\% orangtua mengeluh anak- anaknya sangat

pemilih dalam makan sehingga terjadi defisiensi zat gizi tertentu. (Nor Za'idah Asy'ariyah, 2015) Sehingga WHO menyarankan kepada orangtua agar memberikan asupan gizi seimbang salah satunya dengan mengkonsumsi sayur dan buah sesuai dengan porsinya (Putri Widita Muharyani,2014)

Anak usia prasekolah merupakan suatu periode yang sangat peka terhadap lingkungan dan masa ini berlangsung dengan sangat pendek. Periode ini disebut sebagai masa keemasan ( the golden periode) perkembangan anak, jendela kesempatan dan masa kritis. Masa ini merupakan masa peka atau sensitif, masa pertumbuhan dan perkembangan yang cepat dan penting, memerlukan zat gizi yang cukup baik secara kualitas maupun kuantitasnya.

Dalam proses pertumbuhan dan perkembangan anak usia prasekolah dipengaruhi oleh beberapa faktor seperti pemeliharaan kesehatan, gizi dan stimulasi psikososial. Anak harus dibesarkan dalam lingkungan dan rumah yang sehat, mendapat pelayanan kesehatan dasar (imunisasi), mendapatkan gizi yang cukup dan seimbang, sejak dini ditanamkan kebiasaan hidup bersih. Makan teratur sangat diperlukan oleh anak, karna makan merupakan kebutuhan mendasar bagi hidup manusia serta dengan makan yang teratur sangat diperlukan untuk memenuhi asupan gizi pada manusia. (Marlinda Putri Dejestya, 2016)

Konsumsi sayur dan buah merupakan salah satu syarat dalam memenuhi gizi 
seimbang. Sayur dan buah merupakan makanan yang harus selalu dikonsumsi setiap kali makan. Tidak hanya bagi orang dewasa, mengkonsumsi sayur dan buah sangat penting untuk di konsumsi sejak usia anak anak. Indonesia merupakan negara yang kaya akan sayur-sayuran dan buah-buahan. Konsumsi sayur-sayuran dan buah-buahan bagi masyarakat indonesia masih relatif rendah dibandingkan dengan negara-negara yang tidak memiliki sumber daya sebagai penghasil sayur dan buah (Marlinda Putri Dejestya, 2016).

Anak dapat mempunyai peluang besar untuk menderita kurang gizi karena makanan yang dikonsumsi dalam jumlah sedikit sehingga tidak memenuhi kebutuhan nutrisinya. Selain itu, anak dapat mengalami stunting atau menjadi balita pendek. Untuk itu diperlukan suatu metode untuk meningkatkan pengetahuan dan sikap mengenai pentingnya konsumsi sayur dan buah setiap hari. Oleh sebab itu, sangat perlu dilakukan intervensi sejak dini supaya anak-anak mendapat kesehatan yang optimum. Salah satunya dengan diterapkan terapi Story telling merupakan metode yang sesuai dengan perkembangan kognitif dan afektif anak usia prasekolah. (Nor Za'idah Asy'ariyah, 2015)

Saat story telling berlangsung merupakan proses yang penting, terjadi penyerapan pengetahuan yang disampaikan storyteller kepada audience. Proses inilah yang menjadi pengalaman seorang anak dan menjadi tugas storyteller untuk menampilkan kesan menyenangkan pada saat bercerita. Setelah itu, memilah mana yang dapat dijadikan panutan sehingga membentuknya menjadi moralitas yang dipegang sampai dewasa. Anak akan mengadopsi cerita yang disampaikan oleh storyteller yang berisi tentang pesan-pesan baik; senang makan sayur, tidak rewel dan memilih-milih jenis makanan saat waktu makan tiba. Selanjutnya, anak diharapkan dapat menerapkan pesan-pesan yang disampaikanpada kehidupan sehari-hari. Storytelling merupakan cara yang efektif untuk mengembangkan aspek kognitif, afektif dan aspek kognitif anak.( Nor Za'idah Asy'ariyah, 2015)

\section{BAHAN \& METODE PENELITIAN}

Dalam penelitian ini menggunakan metode one group pre-posttest yaitu jenis penelitian observasi pertama (pretest) yang memungkinkan menguji perubahanperubahan yang terjadi setelah adanya eksperimen (program)(Soekidjo Notoatmojo, 2012). Dalam penelitian ini menggunakan satu kelompok untuk di observasi terhadap kurangnya tingkat konsumsi sayur dan buah sebelum dan sesudah dilakukan story telling.Populasi dalam penelitian ini berjumlah 71 anak usia prasekolah di Tk Al-Ishlah Kabupaten Cirebon. Dalam penelitian ini ada 32 anak yang mengalami kesulitan mengkonsumsi sayur dan buah. Pemilihan sampel dalam penelitian ini menggunakan teknik non random (non probability) sampling yaitu purposive sampling atau didasarkan pada suatu pertimbangan tertentu yang dibuat oleh peneliti sendri, berdasarkan ciri atau sifat- sifat populasi yang sudah diketahui sebelumnya. (Arif Sumantri, 2013) kriteria inklusi dan eksklusi sampel adalah sebagai berikut:

1. Kriteria Inklusi

2. Anak yang bersekolah di Tk Al-Ishlah berusia 3-6 tahun dan mengalami tanda-tanda tidak suka sayur dan buah.

3. Anak dan orangtua dapat diajak berkomunikasi secara verbal

4. Anak dalam keadaan sadar diri (compos metis)

5. Orangtua mengizinkan anaknya dijadikan responden

6. Responden bersedia mengikuti mekanis mepenelitian.

7. Kriteria Eksklusi 
8. Anak yang mengalami cacat fisik

9. Sakit dan tidak masuk sekolah

Metode pengumpulan data berupa data primer yang merupakan data yang diperoleh dari responden melalui observasi langsung atau hasil wawancara peneliti dan data sekunder merupakan data yang didapat dari catatan, buku, artikel, jurnal dan majalah.

\section{HASIL}

Tabel 1. Distribusi responden berdasarkan sebelum dilakukan story telling.

\begin{tabular}{lcl}
\hline Tingkat Konsumsi & Sebelum terapi & Persentase \\
\hline Kurang & IG & $50,0 \%$ \\
Cukup & 9 & 28,1 \\
Baik & 4 & 12,5 \\
Sangat baik & 3 & 9,4 \\
& & \\
\hline
\end{tabular}

Berdasarkan tabel 1. diatas dapat diketahui bahwa dari 32 responden sebanyak 50,0\% atau 16 responden kurang mengonsumsi sayur dan buah.

Tabel 2. Distribusi responden berdasarkan sesudah dilakukan story telling.

\begin{tabular}{lcc}
\hline $\begin{array}{l}\text { Tingkat } \\
\text { Konsumsi }\end{array}$ & Sebelum terapi & Persentase \\
\hline Kurang & 3 & $9,4 \%$ \\
Cukup & 19 & $59,4 \%$ \\
Baik & 5 & $15,6 \%$ \\
Sangat baik & 5 & $15,6 \%$ \\
Total & 32 & $100,0 \%$ \\
\hline
\end{tabular}

Berdasarkan tabel 2. diatas dapat diketahui bahwa dari 32 responden sebanyak 59,4\% atau 19 responden cukup mengkonsumsi sayur dan buah.

Tabel 3. Distribusi responden berdasarkan pengaruh sebelum dan sesudah dilakukan story telling.

\begin{tabular}{lcccc}
\hline Tingkat kansumsi & Sebelum terapi & Sesudah terapi & \\
& & & & \\
\hline & Jumlah & Persentase & Jumlah & Persentase \\
Kurang & 16 & $50,0 \%$ & 3 & $9,4 \%$ \\
Cukup & 9 & $28,1 \%$ & 19 & $59,4 \%$ \\
Baik & 4 & $12,5 \%$ & 5 & $15,6 \%$ \\
Sangat baik & 3 & $9,4 \%$ & 5 & $15,6 \%$ \\
total & 32 & $100,0 \%$ & 32 & $100,0 \%$ \\
\hline
\end{tabular}

Berdasarkan tabel diatas dapat diketahui bahwa dari 32 responden sebanyak 50,0\% atau 16 responden kurang mengonsumsi sayur dan buah. $28,1 \%$ atau 9 responden cukup mengkonsumsi buah dan sayur, $12,5 \%$ atau 4 responden baik mengkonsumsi sayur dan buah dan 9,4\% atau 3 responden sangat baik mengkonsumsi sayur. responden setelah mendapat story telling menunjukan banyak perubahan dalam distribusi kategori jumlah responden sebanyak $9,4 \%$ atau 3 reponden kurang mengkonsumsi sayur dan buah, 59,4\% atau 19 responden cukup mengkonsumsi buah dan sayur, $15,6 \%$ atau 5 responden baik dlam mengkonsi sayur dan buah dan 15,6 atau 5 responden sangat baik dalam mengkonsumsi buah dan sayur.

\section{PEMBAHASAN}

\section{Tingkat Konsumsi Sayur \& Buah} Sebelum Diberikan Terapi

Dari hasil penelitian didapatkan bahwa anak usia prasekolah yang kurang konsumsi sayur dan buah sebanyak 16 responden $(50,0 \%)$. Sedangkan anak usia prasekolah yang cukup mengkonsumsi sayur dan buah sebanyak 9 responden $(28,1 \%)$. Dan anak usia prasekolah yang baik dalam mengkonsumsi sayur dan buah sebanyak 4 responden (12,5\%). Sedangkan anak usia prasekolah yang sangat baik dalam mengkonsumsi sayur dan buah 
sebanyak 3 responden $(9,4 \%)$. Sedangkan anak usia prasekolah yang kurang dalam tingkat konsumsi sayur dan buah sebanyak 16 responden $(50,0 \%)$.

Konsumsi sayur dan buah merupakan salah satu syarat dalam memenuhi gizi seimbang. Sayur dan buah merupakan makanan yang harus selalu dikonsumsi setiap kali makan. Tidak hanya bagi orang dewasa, mengkonsumsi sayur dan buah sangat penting untuk di konsumsi sejak usia anak anak. Indonesia merupakan negara yang kaya akan sayur-sayuran dan buah-buahan. Konsumsi sayur-sayuran dan buah-buahan bagi masyarakat indonesia masih relatif rendah dibandingkan dengan negara-negara yang tidak memiliki sumber daya sebagai penghasil sayur dan buah.

Pola makan dipengaruhi oleh beberapa hal, antara lain adalah kebiasaan, kesenangan, budaya, agama, taraf ekonomi, lingkungan alam dan sebagainya. Makanan selain untuk kekuatan atau pertumbuhan, memenuhi rasa lapar dan selera, juga mendapat tempat sebagai lambang yaitu lambang kemakmuran, kekuasaan, ketentraman, dan persahabatan. Semua faktor diatas bercampur membentuk suatu ramuan yang kompak yang disebut dengan pola konsumsi. sejalan dengan pendapat sandjaja , pola makan konsumsi adalah susunan makanan yang mencakup jenis dan jumlah bahan makanan rata-rata per orang per hari yang umum dikonsumsi atau dimakan pendududuk dalam jangka tertentu.

Masalah makan yang terjadi pada umumnya adalah kesulitan makan, karena dari hari kehari umumnya nafsu makannya tidak menentu. Kesulitan makan adalah ketidak mampuan untuk makan dan menolak makanan tertentu sejalan dengan pendapat santoso, hal ini penting diperhatikan karena dapat menghambat tumbuh kembang optimal pada anak.
Kewajiban orangtua adalah memperhatikan jumlah makanan dan kondisi makanannya setiap hari.

Makan merupakan hal yang kurang menyenangkan untuk anak karena pada usia ini yang menggembirakan adalah bermain. Permainan merupakan media dan ajang peningkatan keterampilanya. Anak akan tetap memperoleh asupan gizi ketika dia sedang bermain, belajar dan bersosialisasi melalui permainan. Sejak usia ini mulai terlihat adanya tanda-tanda sikap pribadi anak anak yang menyukai dan tidak menyukai makanan tertentu. Menolak makanan terutama sayuran sangat umum pada anak usia prasekolah. Tidak ada satupun jenis bahan makanan yang esensial sehingga jika satu jenis ditolak dapat diganti dengan jenis lain yang nilai gizinya setara.Dari hasil penelitian yang pernah dilakukan untuk mengetahui pengaruh story telling bermain cerita untuk lebih sering mnegkonsumsi buah dan sayur pada anak usia prasekolah. (Fadillah Fitriani, 2016)

Dari hasil penelitian diatas peneliti dapat berasumsi bahwa penyebab kategori kurang dalam mengkonsumsi sayur dan buah sangat tinggi di $\mathrm{Tk}$ Al- Ishlah Kabupaten Cirebon dikarenakan tampilan sayur dan buah yang kurang bervariatif serta keterbatasan pengetahuan orangtua dalam pengenalan pengolahan makanan.

Pengetahuan orangtua sangat mendukung dalam pemenuhan kebutuhan konsumsi sayur dan buah. Orangtua yang tahu dan faham bagaimana membuat berbagai jenis varian dan olahan sayur dan buah akan mampu memodivikasi sayur dan buah tanpa mengurangi kandungan atau nilai gizi sayur dan buah tersebut.

\section{Tingkat Konsumsi Sayur \& Buah sesudah Diberikan Story telling}


Data penelitian menunjukan bahwa sebagian besar anak prasekolah sesudah diberikan story telling mengalami peningkatan konsumsi sayur dan buah, sebanyak 9,4\% atau 3 reponden kurang mengkonsumsi sayur dan buah, 59,4\% atau 19 responden cukup mengkonsumsi buah dan sayur, 15,6\% atau 5 responden baik dlam mengkonsi sayur dan buah dan 15,6 atau 5 responden sangat baik dalam mengkonsumsi buah dan sayur.dibandingkan dengan tingkat konsumsi sebelum diberikan terapi story telling nampak bahwa terjadi peningkatan tingkat konsumsi sayur dan buah setelah dilakukan story telling.Beberapa faktor yang mempengaruhi peningkatan konsumsi sayur dan buah adalah perubahan pada pola konsumsi sayur dan buah dalam kategori kurang menjadi lebih adaptif secara fisiologis dan efektif.

Story telling adalah salah satu metode untuk meningkatkan pengetahuan dan sikap mengenai pentingnya makan sayur setiap hari. Dongeng bisa menjadi wahana untuk mengasah imajinasi,membuka pemahaman dan belajar pada pengelamanpengalaman sang tokoh dalam dongeng tersebut. Teknik bercerita merupakan cara yang unik, menarik tanpa memaksa dan tanpa perlu menggurui sang anak. Mendongeng mempunyai banyak kegunaan di dalam pendidikan utama anak. Dia menyimpulkan bahwa dongeng menyediakan suatu kerangka konseptual untuk berpikir, yang menyebabkan anak dapat membentuk pengalaman menjadi keseluruhan yang dapat mereka pahami. Dongeng menyebabkan mereka dapat memetakan secara mental pengalaman dan melihat gambaran di dalam kepala mereka, mendongengkan dongeng tradisional menyediakan anak-anak suatu model bahasa dan pikiran bahwa mereka dapat meniru. ${ }^{(14)}$ Tujuan dari story telling ini adalah untuk meningkatkan konsumsi sayur dan buah yang dapat berpengaruh dalam pertumbuhan dan perkembangan anak prasekolah.

Data uji analisis data dapat dinyatakan terdapat Efektifitas metode story telling pada kebiasaan pola makan pada anak usia dini Nor Za'idah Asy'ariyah ${ }^{(2)}$ dengan hasil uji statistik pada kelompok perlakuan $\mathrm{p}=0,000$ dimna $\mathrm{P}=<\quad 0,05$ maka $\mathrm{H}_{1}$ diterima, artinya ada perbedaan saat pretest dan postest pada kelompok perlakuan. Pada kelompok kontrol lain $\mathrm{P}=0,000$ dimana $\mathrm{P}>0,005$, maka $\mathrm{H}_{1}$ ditolak, artinya tidak ditemukan perubahan tingkat konsumsi sayur dan buah yang bermakna. Berdasarkan uraian yang sudah dijelaskan diatas, maka peneliti dapat berasumsi bahwa perubahan tingkat konsumsi sayur dan buah pada anak usia prasekolah di Tk Al-Ishlah Kabupaten Cirebon cukup tinggi yaitu 59,4\%. Story telling yang disampaikan tidaklah cukup hanya tema cerita saja yang berbeda namun perlu ada pendekatan terhadap anak usia prasekolah, teknik bercerita agar lebih menarik dan tidak membosankan. Story telling tidak hanya dapat dilakukan 1 minggu sekali namun dapat dilakukan seminggu 2 kali dengan tema cerita yang berbeda, orangtua pun diberikan edukasi dalam menyampaikan story telling dan manfaat story telling.

\section{Pengaruh story telling terhadap tingkat konsumsi sayur dan buah pada anak usia prasekolah di Tk Al-Ishlah Kabupaten Cirebon}

Hasil pengujian hipotesis menggunakan uji Wilcoxon Signed Rank test diperoleh nilai probabilitas ( $p$-value) sebesar 0,000 sehingga kesimpulan uji adalah terhadap Pengaruh story telling terhadap tingkat konsumsi sayur dan buah pada anak usia prasekolah di Tk Al-Ishlah Kabupaten Cirebon. Sesuai dengan penelitian sebelumnya dapat disimpulkan bahwa hasil terapi story telling dapat 
meningkatkan tingkat konsumsi sayur dan buah pada anak prasekolah.

Pada dasarnya Konsumsi sayur dan buah merupakan salah satu syarat dalam memenuhi gizi seimbang. Sayur dan buah merupakan makanan yang harus selalu dikonsumsi setiap kali makan. Tidak hanya bagi orang dewasa, mengkonsumsi sayur dan buah sangat penting untuk di konsumsi sejak usia anak anak. Indonesia merupakan negara yang kaya akan sayur-sayuran dan buah-buahan. Konsumsi sayur-sayuran dan buah-buahan bagi masyarakat indonesia masih relatif rendah dibandingkan dengan negara-negara yang tidak memiliki sumber daya sebagai penghasil sayur dan buah. Berdasarkan hasil penelitian yang ada peneliti berpendapat bahwa adanya pengaruh story telling terhadap tingkat konsumsi sayur dan buah. Hal ini didukung dengan adanya efek dari story telling yang membantu dalam meningkatkan konsumsi sayur dan buah pada nak prasekolah.

\section{KESIMPULAN}

1. Sebelum dilakukan Story telling dari 32 responden, yang kurang mengkonsumsi sayur dan buah sebanyak 16 orang $50 \%$

2. Setelah dilakukan Story telling dari 32 responden, yang cukup mengkonsumsi sayur dan buah sebanyak 19 orang $59,4 \%$

3. Ada pengaruh antara story telling terhadap tingkat konsumsi sayur dan buah padaanakusiaprasekolah di $\mathrm{Tk}$ Al-IshlahKabupaten Cirebon tahun $2017(p$ value $=0,000)$.

\section{SARAN}

1. Keperawatan Anak

Hasil penelitian ini diharapkan dapat menjadi bahan masukan untuk meningkatkan dan mengembangkan pendidikan terapi story telling terkait dengan proses tingkat konsumsi sayur dan buah pada anak usia prasekolah.

2. Sekolah Tk

Hasil penelitian ini diharapkan dapat memberi masukan bagi sekolah untuk meningkatkan fasilitas bermain sesuai dengan tumbuh kembang anak serta sarana pelaksanaan story telling.

3. Penelitian Lain

Peneliti ini diharapkan dapat menjadi data dasar bagi peneliti lain yang akan melakukan penelitian dalam konteks ruang lingkup yang sama, sehingga sumber dari sebuah kutipan yang terdapat dalam penelitian ini dapat dijadikan sebagai referensi dan pembanding dalam membandingkan penelitian.

\section{DAFTAR PUSTAKA}

Putri Widita Muharyani. Hubungan Kontrol Makanan, Model Peran Keterlibatan Anak Dengan Sulit Makan Pada Anak.2014; vol3:34

Nor Za'idah Asy'ariyah, Yuni Sufyanti Arief, Ilya Krisnana. Story Telling Sebagai Upaya Meningkatkan Konsumsi Makan Sayur. 2015; vol. $3: 73$

Marlinda Putri Dejestya.Skripsi Pola Konsumsi Sayur Dan Buah: Faktor Yang mempengaruhi Konsumsi Sayur Dan Buah. Brebes; 2016. Hal.23

Prof. Dr. Soekidjo Notoatmojo. Metodologi Penelitian Kesehatan. November 2012

Fadillah Fitriani, Fatmalina Febry, Rini Mutahar. Gambaran Penyebab 
Kesulitan Makan Pada Anak

2011;3.30-nov-2016

Prasekolah Usia 3-5 Tahun

72 | Jurnal Skolastik Keperawatan | Vol.4, No.1 | Jan - Jun 2018 